\title{
Class III metallothioneins in response to cadmium toxicity in the marine microalga Tetraselmis suecica (Kylin) Butch
}

\author{
Mónica Pérez-Rama, Concepción Herrero López, Julio Abalde Alonso and \\ Enrique Torres Vaamonde
}

Departamento de Biología Celular y Molecular, Laboratorio de Microbiología, Facultad de Ciencias, Universidade da Coruña, Campus da Zapateira s/n. 15071, La Coruña, España

\section{Environmental Toxicology and Chemistry}

First published: September 2001

Manuscript Accepted: 1 February 2001

Manuscript Received: 30 May 2000

This is the peer reviewed version of the following article:

Pérez-Rama, M., Herrero, C., Abalde, J. and Torres, E. (2001), Class III metallothioneins in response to cadmium toxicity in the marine microalga Tetraselmis suecica (Kylin) Butch. Environmental Toxicology and Chemistry, 20: 2061-2066. doi:10.1002/etc.5620200927

which has been published in final form at http://dx.doi.org/10.1002/etc.5620200927. This article may be used for non-commercial purposes in accordance with Wiley Terms and Conditions for Self-Archiving

\begin{abstract}
Microalgae are one of the most important organisms in our ecosystems being seriously affected by metal pollution. However, the microalgae Tetraselmis suecica (Kylin) Butch is tolerant to cadmium; the concentration of this metal that reduces the population growth to $50 \%$ of the control growth level is $5.8 \mathrm{mg} / \mathrm{L}$ after $96 \mathrm{~h}$ of exposure. In this study, class III metallothioneins
\end{abstract}


were investigated for their involvement as a possible tolerance mechanism in this microalga when exposed to cadmium. A set of these molecules was purified from these microalgal cells after exposure to the metal. These polypeptides were analyzed by capillary zone electrophoresis, which is a technique that allows the length of the metallothioneins synthesized by this microalga to be known. The T. suecica cells were able to synthesize class III metallothioneins of three to six subunits of ( $\gamma$-Glu-Cys). The most abundant polypeptide possessed four subunits, and $(\gamma-$ Glu-Cys) ${ }_{6}$-Gly was the largest polypeptide synthesized by this microalga and detected by this technique. Tolerance to cadmium as a function of increasing polypeptide length is also discussed.

\section{KEYWORDS}

Cadmium, Microalga, Toxicity, Tolerance, Class III metallothioneins

\section{INTRODUCTION}

Nonessential metal ions can inhibit a variety of metabolic activities and be detrimental to cellular processes. This also happens when essential metal ions are present at high concentrations above a specific threshold.

As a consequence of the industrial revolution, demand for metals is enormous and increasing, which leads to high anthropogenic emission of these elements in the environment. Metals in aquatic environments persist, because in contrast to herbicides, pesticides, and other potential pollutants, they do not break down and, instead, persist in sediments, being slowly released into the water and becoming available to the organisms [1].

Cadmium is a common industrial pollutant, the concentration of which has increased in various environments during the last decades. Cadmium is a nonessential metal that produces serious hazards to aquatic organisms, including microalgae $[\mathbf{2 , 3}$. The toxic effect of cadmium on microalgae is relevant, because these organisms constitute the base of the marine food chain.

Microalgae, like other organisms, have developed different protective mechanisms to tolerate exposure to metal poisoning. One of the most studied mechanisms during the last few years is the synthesis of metallothioneins. In response to excessive uptake of metals, microalgae induce metal-binding peptides, which are referred to as class III metallothioneins. Several studies have confirmed the ubiquity of class III metallothionein synthesis in response to cadmium in microalgae [4-7]. These molecules have attracted considerable interest regarding their 
biochemical and environmental aspects [8], not because of their role in the detoxification of metals but also because they could be involved in metal ion homeostasis as essential metal ion reservoirs [9]. In plant cells, class III metallothioneins could play a role in sulfur metabolism as well [10].

Class III metallothioneins are polypeptides with the amino acid structure ( $\gamma$-Glu-Cys) $)_{n}$-Gly, where $n$ ranges from 2 to 11 . An enzyme, $\gamma$-glutamylcysteine transpeptidase, which is isolated from a higher plant, catalyzes class III metallothionein formation [11]. The enzyme transfers the $\gamma$-glutamylcysteine dipeptide from one glutathione molecule to another glutathione as an acceptor molecule. This reaction can thus proceed sequentially to yield progressively larger peptides.

This enzyme has been given the trivial name phytochelatin synthase, because it was first purified from plant cells [11]. Class III metallothionein synthase (i.e., phytochelatin synthase) is present constitutively in cells. Studies of the enzyme in vitro have demonstrated that cadmium is the most effective activator, followed (generally) by $\mathrm{Ag}, \mathrm{Bi}, \mathrm{Pb}, \mathrm{Zn}, \mathrm{Cu}, \mathrm{Hg}$, and $\mathrm{Au}[\mathbf{1 1 , 1 2}]$, depending on the species of test organism used in the study.

Class III metallothioneins chelate metals through coordination with the sulfhydryl group in cysteine, forming thiolatemetal complexes. After the metal enters the cytosol of the cell, it is immediately complexed and inactivated. This action avoids the inhibitory effect of metal on active catalytic sites or on structural proteins [13]. Class III metallothioneins may be a component of a shuttle system for the transfer of metals from the cytoplasm to the vacuoles $[14,15]$.

Class III metallothioneins are widespread among microalgae. In this study, the ability of the marine microalga Tetraselmis suecica (Kylin) Butch to synthesize class III metallothioneins in response to cadmium was assayed. Moreover, the class III metallothioneins synthesized by this microalga were characterized using a capillary electrophoresis technique, which was used to separate and identify the class III metallothioneins.

\section{MATERIALS AND METHODS}

\section{Effect of cadmium toxicity on growth}

The T. suecica cells were grown in batch conditions in natural, organic-free seawater to determine the effect of cadmium on growth. The seawater was passed through a $0.45-\mu \mathrm{m}$ Millipore filter (Milli-Q Corp., Bedford, MA, USA) and a charcoal column to eliminate organic chelating substances and, subsequently, sterilized at $121^{\circ} \mathrm{C}$ for $20 \mathrm{~min}$. The assay was carried 
out in this natural, unenriched seawater, with no inorganic nutrients added. The salinity of the seawater was $35 \%$, and the initial $\mathrm{pH}$ of the culture was 8 .

Stock solution of cadmium was prepared by dilution of $\mathrm{CdCl}_{2}$ in Milli-Q water to a final concentration of $10 \mathrm{~g} / \mathrm{L}$ of cadmium. For the experiment, appropriate volumes of the stock solution were added to the natural seawater to obtain cadmium concentrations of $0.6,3,6,15$, 30, 45, and $60 \mathrm{mg} / \mathrm{L}$. Control cultures without cadmium were also included.

Cultures were carried out in triplicate in Kimax test tubes (Kimble Glass, Vineland, NJ, USA) containing $40 \mathrm{ml}$ of this natural seawater. The tubes were previously rinsed with nitric acid as well as several times with Milli-Q water. Cultures were maintained at $18 \pm 1{ }^{\circ} \mathrm{C}$ and $68 \mu \mathrm{E} / \mathrm{m}^{2} / \mathrm{s}$, with a 12:12 photoperiod for $4 \mathrm{~d}$. Initial cell density was $25 \times 10^{4}$ cells $/ \mathrm{ml}$. Cultures were gently shaken every day to ensure homogeneous exposure to the metal. Growth of microalgal cultures was measured daily by counting culture aliquots in a Neubauer (Blaubrand, Brand, Germany) hemocytometer chamber after fixation with Lugol (Central Scientific, Franklin Park, IL, USA).

The concentration of cadmium that reduces the population growth to $50 \%$ of the control growth level (EC50) was calculated by probit analysis [16].

\section{Class III metallothionein synthesis}

Culture conditions. The metallothionein induction assay was carried out in seawater enriched with inorganic nutrients [17] but without ethylenediaminetetraacetic acid (EDTA) and Tris. Cultures were grown in triplicate in glass bottles (Pyrex ${ }^{\mathrm{TM}}$; Corning, New York, NY, USA) with natural, sterile air at a flow rate of $10 \mathrm{~L} / \mathrm{min}$. Cultures were maintained at $18 \pm 1{ }^{\circ} \mathrm{C}$ and 68 $\mu \mathrm{E} / \mathrm{m}^{2} / \mathrm{s}$, with a $12: 12$ photoperiod. Initial cell density was $25 \times 10^{4}$ cells $/ \mathrm{ml}$. These culture conditions were necessary for achieving better growth. Cultures were maintained until sufficient cells were obtained, because larger amounts of biomass are required to detect and purify metallothioneins.

The cadmium concentration used for metallothionein induction experiments was $6 \mathrm{mg} / \mathrm{L}$. Cultures without cadmium were also included as controls.

Nonprotein thiol-rich compound extraction and detection in crude extracts. Nonprotein thiolrich compounds were determined in acid crude extracts according to the method described by Ellman [18]. Cells from cultures not exposed to cadmium and from cultures exposed to $6 \mathrm{mg} / \mathrm{L}$ of cadmium were collected by centrifugation $(12,000 \mathrm{~g}$ for $10 \mathrm{~min})$ and washed with metal-free seawater. The cell pellet was then re-suspended in $0.1 \mathrm{M} \mathrm{HCl}$, and the cells were homogenized with an ultrasonic cell disrupter for $3 \mathrm{~min}$ at $14 \mu \mathrm{m}$. Unbroken cells and cellular debris were removed by centrifugation at $12,000 \mathrm{~g}$ for $15 \mathrm{~min}$ at $4^{\circ} \mathrm{C}$. 
An aliquot of $400 \mu \mathrm{l}$ of the acid extract was mixed with $700 \mu \mathrm{l}$ of a solution containing $10 \mathrm{mM}$ dithiobis-nitrobenzoic acid, Ellman reagent, and $1 \mathrm{mM}$ EDTA in $0.5 \mathrm{M}$ sodium phosphate buffer ( $\mathrm{pH}$ 7.5). After $2 \mathrm{~min}$ of reaction, the absorption was recorded at $412 \mathrm{~nm}$. Values were corrected for the absorbance of the reagents and of the extracts.

Glutathione was used as a suitable calibrating substance for quantitating the thiols.

Purification of metallothionein complexes. Cadmium metallothioneins were purified by gelfiltration chromatography. Alkaline extracts were prepared from cells exposed to $6 \mathrm{mg} / \mathrm{L}$ of cadmium for $8 \mathrm{~d}$ and from cells not exposed to cadmium. Cells were collected by centrifugation $(12,000 \mathrm{~g}$ for $10 \mathrm{~min})$ and washed with metal-free seawater. The cell pellet was re-suspended in $75 \mathrm{mM}$ sodium borate buffer ( $\mathrm{pH} 8.6$ ), and the cells were disrupted and clarified as in the acid extracts.

One milliliter of these alkaline extracts was applied to a Biogel P-60 (Bio-Rad Laboratories, Hercules, CA, USA) gel-filtration column $(2.5 \times 60 \mathrm{~cm})$ equilibrated with $75 \mathrm{mM}$ sodium borate buffer ( $\mathrm{pH} 8.6)$. The extracts were eluted in the same buffer at a flow rate of $0.4 \mathrm{ml} / \mathrm{min}$ and at room temperature $\left(23 \pm 2^{\circ} \mathrm{C}\right)$. The absorption of the eluates was monitored at $254 \mathrm{~nm}$, and fractions of $4 \mathrm{ml}$ were collected.

The metallothionein-containing fractions in the cellular extracts were located by cadmium analysis and by measurement of the thiol content of an aliquot of each fraction. An aliquot of each fraction was acidified with nitric acid, and then cadmium was measured by inductively coupled plasma-mass spectrometry using a VG Elemental Plasma Quad 2 ICP-MS System (VG Elemental, Offenbach, Germany). Thiol groups were detected and measured in all fractions according to the method described by Ellman [18].

\section{Analysis of metallothioneins}

Determination of amino acid content. The purified fraction containing the highest concentration of cadmium and thiol groups was analyzed to determine the amino acid composition. Amino acid composition was determined after cysteine stabilization with 3,3'-dithiodipropionic acid (DTDPA) by high-performance liquid chromatography (HPLC) [19] using a HP 1046A HPLC system equipped with an HP 1050 fluorescence detector (Hewlett-Packard, Waldbronn, Germany).

Aliquots from the purified fraction were mixed with a solution containing 10\% (w/v) DTDPA dissolved in borate buffer $(0.4 \mathrm{~N}, \mathrm{pH} 10.4)$. After $1 \mathrm{~h}$, the hydrolysis was produced by addition of $\mathrm{HCl}$ and phenol at final concentrations of $6 \mathrm{~N}$ and $0.1 \%(\mathrm{w} / \mathrm{v})$, respectively. The tube containing the mixture was sealed and hydrolyzed for $24 \mathrm{~h}$ at $110^{\circ} \mathrm{C}$. The tube was then cooled, 
and the sample was evaporated to dryness. Finally, the sample was reconstituted in the borate buffer and centrifuged at $12,000 \mathrm{~g}$ for $10 \mathrm{~min}$ at $4^{\circ} \mathrm{C}$.

The amino acids were analyzed by HPLC after derivatization with $o$-phthaldialdehyde for primary amino acids and with 9-fluorenylmethylchloro-formate for secondary amino acids using a $\mathrm{C}_{18}$ ODS Hypersil, 5- $\mu \mathrm{m}$ column $(250 \times 4 \mathrm{~mm})$ equipped with a guard column Lichrospher 100RP-18 (5 $\mu \mathrm{m}, 4 \times 4$ mm; Merck, Darmstadt, Germany). The chromatographic procedure was the same as that described by Godel et al. [20]. Chromatograms were recorded and analyzed with the Chemstation HPLC ${ }^{3 \mathrm{D}}$ data processing software (Hewlett-Packard).

Capillary electrophoresis. The fraction containing the highest concentrations of thiol groups and cadmium was analyzed by capillary electrophoresis. The electrophoretic analysis was performed on a $\mathrm{HP}^{3 \mathrm{D}} \mathrm{CE}$ Capillary Electrophoresis System (Hewlett-Packard) using an uncoated, fused silica capillary (inner diameter, $50 \mu \mathrm{m}$; total length, $37.5 \mathrm{~cm}$ ). Ultraviolet detection was fixed at a wavelength of $200 \mathrm{~nm}$.

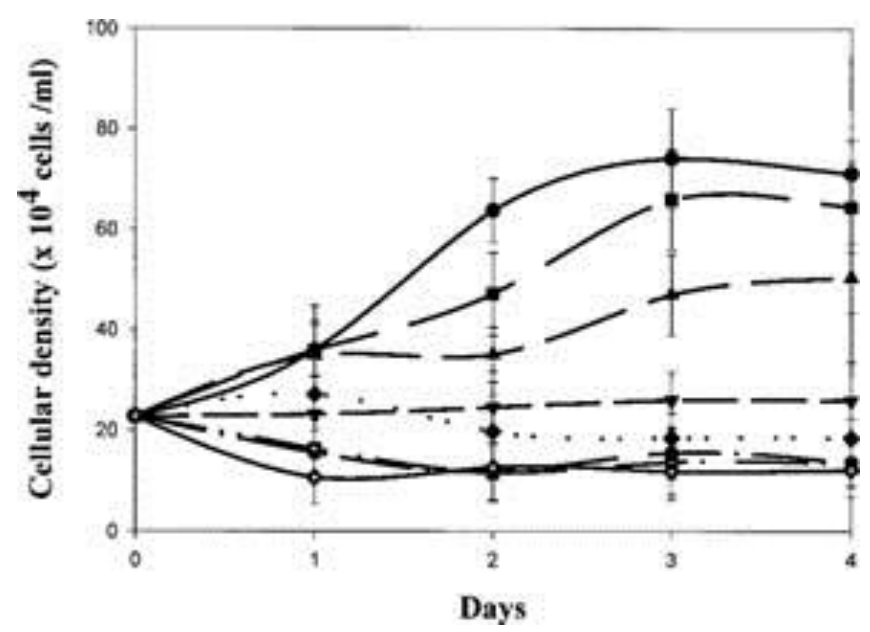

\section{Figure Fig. 1.}

Growth of Tetraselmis suecica cells with the different cadmium concentrations assayed. $\cdot=$ Control, $\cdot=0.6 \mathrm{mg} / \mathrm{L}, \Delta=3 \mathrm{mg} / \mathrm{L}, \nabla=6 \mathrm{mg} / \mathrm{L}, \diamond=15 \mathrm{mg} / \mathrm{L}, \circ=30 \mathrm{mg} / \mathrm{L}, \square=45 \mathrm{mg} / \mathrm{L}, \diamond=60$ $\mathrm{mg} / \mathrm{L}$. Data are means $\pm \mathrm{SD}(n=3)$.

Before the runs, the capillary was rinsed with $1 \mathrm{M}$ sodium hydroxide solution, distilled water, and $1 \mathrm{M} \mathrm{HCl}$ and then conditioned for 3 min with the running buffer. The running buffer was $150 \mathrm{mM}$ phosphoric acid with $2 \%(\mathrm{v} / \mathrm{v})$ acetonitrile as an organic modifier. Between each injection, the capillary was consecutively washed for 2 min with $0.1 \mathrm{M} \mathrm{HCl}$ and Milli-Q water to remove surface-adhered material and to maintain separation reproducibility. Finally, the 
capillary was filled with running buffer. Injection of the sample into the capillary was at the anode by pressure at 50 mbar. Electrophoresis was carried out by applying $+12 \mathrm{kV}$ in a constant-voltage mode at room temperature $\left(23 \pm 2^{\circ} \mathrm{C}\right)$.

\section{RESULTS}

\section{Growth}

Figure 1 shows a significant effect (analysis of variance, $p<0.001$ ) of cadmium on growth of $T$. suecica after $96 \mathrm{~h}$ of exposure. Exposure of $T$. suecica cells to increasing cadmium concentrations resulted in progressive inhibition of growth. As cadmium concentration increased in the medium, growth decreased. Control cultures and cultures exposed to 0.6 and 3 $\mathrm{mg} / \mathrm{L}$ of cadmium reached the stationary phase in $3 \mathrm{~d}$, whereas in the cultures exposed to 6 $\mathrm{mg} / \mathrm{L}$, only a small increase in cell density occurred. Cultures exposed to the highest cadmium concentrations $(15,30,45$, and $60 \mathrm{mg} / \mathrm{L})$ did not grow at all.

The statistical analysis using Duncan's multiple range test showed that the toxic effect of the different cadmium concentrations assayed on $T$. suecica growth could be expressed as

$$
\text { Control }=0.6<3<6<15=30=4560
$$

Therefore, in these culture conditions, a cadmium concentration of $0.6 \mathrm{mg} / \mathrm{L}$ or less had no detectable effect on growth of microalgal cells, but at higher cadmium levels, growth rates decreased.

The median effective concentration (EC50) for this microalga was estimated at $5.8 \mathrm{mg} / \mathrm{L}$ of cadmium after $96 \mathrm{~h}$ of exposure.

\section{Analysis of metallothioneins}

Initial screening for cadmium-binding polypeptides was the measure of thiol group evolution in cultures exposed to cadmium.

An increase in the concentration of thiol groups was observed over time in $T$. suecica cells exposed to cadmium (Fig. 2), whereas thiol content in the cells not exposed to cadmium did not change during the experiment. In cells exposed to cadmium, thiol concentration fitted a sigmoidal curve, with $R^{2}=0.99$. A rapid increase occurred in thiol groups, reaching the highest concentration in $6 \mathrm{~d}$, with $30.8 \times 10^{-6} \mu \mathrm{M}-\mathrm{SH} /$ cell. The presence of thiol-rich compounds in the microalgae was considered to be the first presumptive evidence of metal-binding polypeptides 
in these cells. Therefore, $T$. suecicacells exposed to cadmium are able to synthesize and accumulate compounds with thiol groups.

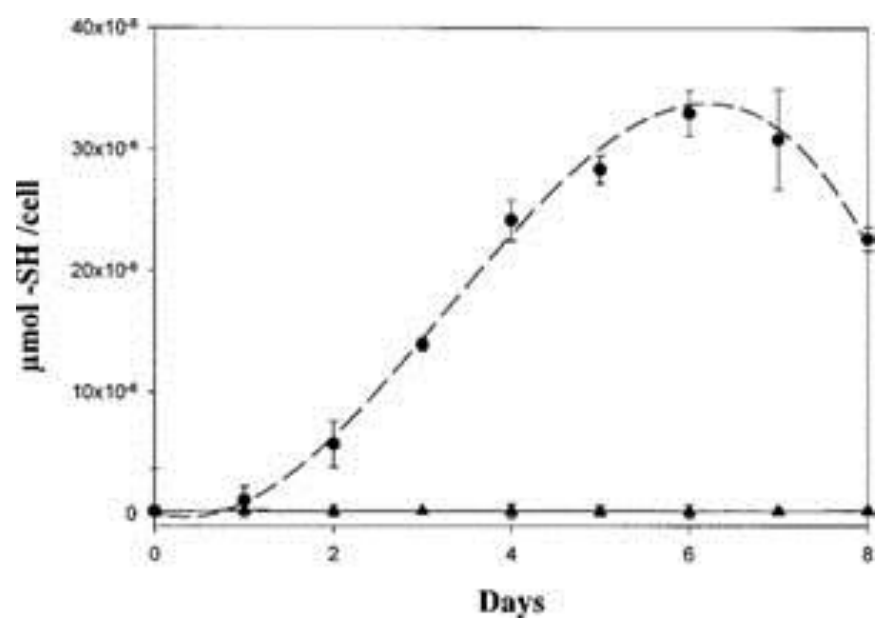

Figure Fig. 2.

Time course of thiol groups in Tetraselmis suecica cultures exposed to $6 \mathrm{mg} / \mathrm{L}$ of cadmium during $8 \mathrm{~d}(\bullet)$ and in control cultures $(\bullet)$. Data are means $\pm \operatorname{SD}(n=3)$.

Purification of these molecules induced by cadmium was performed by gel-filtration chromatography. Crude, cell-free extracts of untreated cells and of treated cells cultured for $6 \mathrm{~d}$ with $6 \mathrm{mg} / \mathrm{L}$ of cadmium were examined. Typical separations of these extracts are shown in Figure 3. Absorbance was measured at $254 \mathrm{~nm}$, with a new peak appearing in the chromatogram of cadmium-exposed cells (Fig. 3b). This peak did not appear in the chromatogram of control cells (Fig. 3a). The higher concentration of thiol groups corresponded to this new peak in the chromatogram of cells exposed to cadmium (Fig. 3b). Similarly, metal analysis showed that the fractions of this peak (fractions 21-33) had the highest cadmium concentration, with $86.71 \%$ of the cadmium present in the initial extract applied to the gel-filtration column. The appearance of cadmium-enriched thiol fractions indicates the presence of thiolate-metal complexes.

When the cadmium-enriched thiol fractions separated by gel permeation chromatography were subjected to amino acid analysis, only three amino acids were detected: glycine, glutamic acid, and cysteine. Glutamic acid and cysteine were the most abundant amino acids. Therefore, from these data, the new peak fractions clearly correspond to class III metallothioneins. These molecules were induced in response to cadmium exposure and characterized by the presence of 
thiolate-metal complexes, and the amino acid composition was the same as that for class III metallothioneins.

Thiol groups were identified as class III metallothionein. The level of these cadmium-binding polypeptides in $T$. suecica cells also increased with time of exposure to cadmium (Fig. 2). Capillary electrophoresis was used to characterize these cadmium-binding polypeptides synthesized in response to cadmium [21]. Running buffer was added with $2 \%(\mathrm{v} / \mathrm{v})$ acetonitrile (organic modifier) that allowed class III metallothioneins peaks to be sharper and the resolution to be increased.
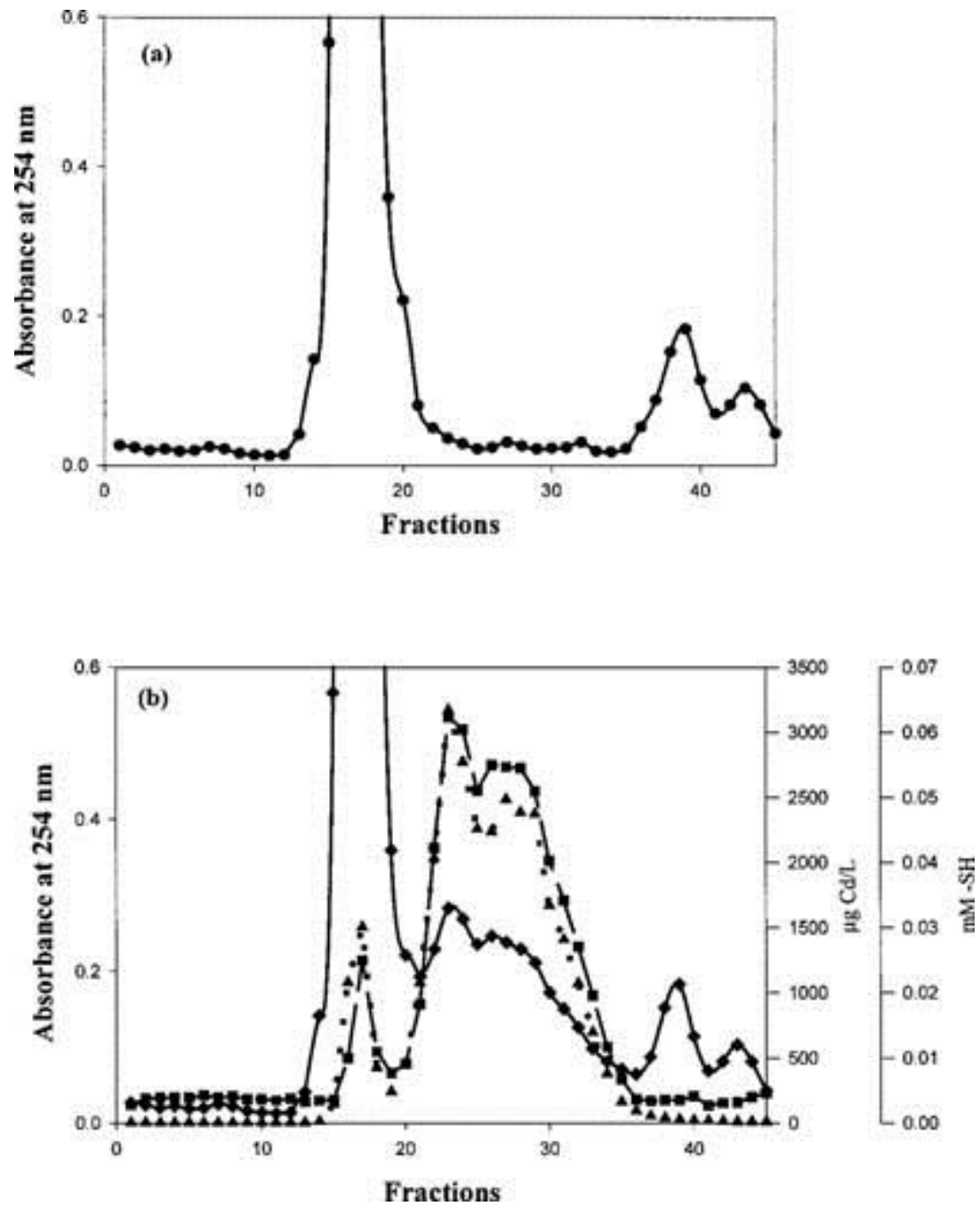

Figure Fig. 3..

Typical chromatograms obtained by gel-filtration chromatography from Tetraselmis suecica cells not exposed (a) and exposed to $6 \mathrm{mg} / \mathrm{L}$ of cadmium for $6 \mathrm{~d}(\mathbf{b}) \cdot \cdot=$ Absorbance at $254 \mathrm{~nm}, \cdot=-$ SH groups, $\boldsymbol{\wedge}=$ cadmium . 
The electropherogram (Fig. 4) of the class III metallothioneins purified from $T$. suecica cells distinguished four peaks, each corresponding to a metallothionein with a different number of subunits. The presence of various peaks in the fraction containing metallothioneins indicates that these molecules form a complex of metallothioneins with different chain lengths.

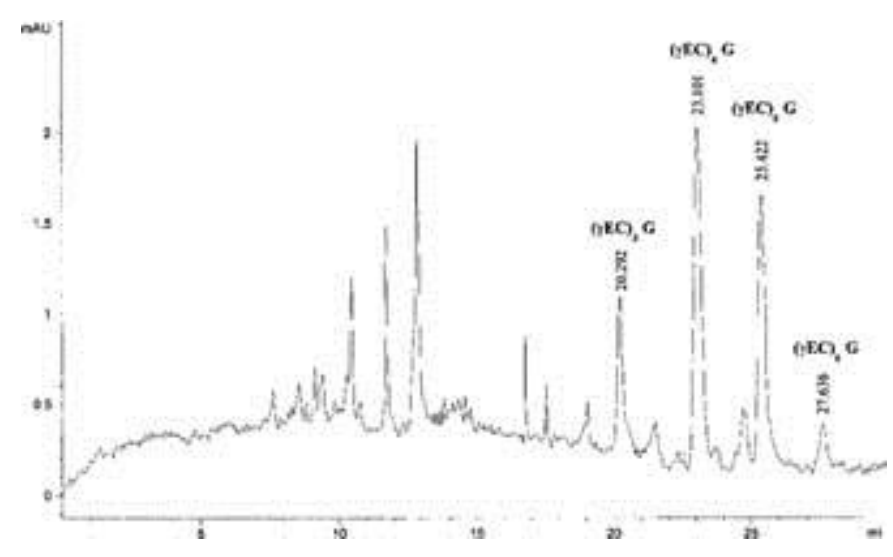

Figure Fig. 4..

Electropherogram obtained by capillary electrophoresis of the fraction containing the highest concentration of class III metallothioneins $\left[(\gamma \mathrm{EC})_{\mathrm{n}} \mathrm{G}\right]$.

This electrophoretic technique allowed determination of the length of these polypeptides [21]. The $T$. suecica cells exposed to cadmium were able to synthesize metallothioneins of three to six subunits of ( $\gamma$-Glu-Cys). The most abundant polypeptide was ( $\gamma$-Glu-Cys) $)_{4}$-Gly, and the largest polypeptide detected by this technique contained six subunits.

\section{DISCUSSION}

Microalgae are one of the most important organisms in our ecosystem, because they are the main primary producers and the base of the food chain. Microalgae are characterized by their rapid growth rates and ubiquitous distribution in natural environments, and they show greater sensitivity to environmental variation (e.g., nutrients and pollutants). This is why the use of microalgae as test organisms is gaining support. Furthermore, algal toxicity tests are quick, inexpensive, and can be used effectively to assess those toxic substances that are found in concentrations too low for effective detection by higher trophic organisms [22]. 
Cadmium is one of the most toxic metals, with no described biological function. Due to a great affinity to sulfhydryl groups, cadmium can inactivate many important enzymes, resulting in the inhibition of growth, photosynthesis, respiratory rate, and other cell processes [3]. Several studies have been reported concerning the effect of cadmium on growth of microalgal cells [23]. Growth is a good indicator for the toxic action of cadmium in microorganisms, and it reflects the metabolism of the cell.

The effect of cadmium on growth depends on the microalgal species.Tetraselmis suecica tolerates high concentrations of cadmium. In this study, a concentration of $3 \mathrm{mg} / \mathrm{L}$ or higher affected the growth of T. suecica cells (Fig.1). The EC50 calculated for this microalga after $96 \mathrm{~h}$ of exposure to this metal was $5.8 \mathrm{mg} / \mathrm{L}$.

Interspecies differences in microalgal cadmium tolerance have been reported. Microcystis aeruginosa, Scenedesmus quadricauda, Aulacoseira granulata, Anabaena variabilis, Chlorella vulgaris, and Haematococcus capensisare among the microalgae most sensitive to cadmium, with their growth being inhibited at $5.6 \times 10^{-4}, 1.87 \times 10^{-3}, 2.13 \times 10^{-3}, 0.01,0.1$, and $0.1 \mathrm{mg} / \mathrm{L}$ of cadmium, respectively [2,24]. Scenedemus obliquus, Ankistrodemus falcatus, Chlorococcum sp., Navicula incerta, and T. gracilis are more tolerant to cadmium, with their growth being inhibited at 2.5, 2.5, 3, 3.01, and $3.2 \mathrm{mg} / \mathrm{L}$ [24]. Therefore, $T$. suecica can be included in the group of microalgal species most tolerant of cadmium.

Many metals induce production of class III metallothioneins, although the magnitude of the response depends on the particular metal [25]. Production of these peptides is believed to be a general detoxification system in many cells. Thus, Wikfors et al. [6] selected microalgal strains with laboratory-induced cadmium tolerance. They found that Phaeodactylum tricornutumstrains grew in concentrations that were acutely toxic to the original $P$. tricornutum strain from which they were derived, and that these tolerant strains produced more ( $\gamma$-Glu-Cys) $)_{n}$-Gly than the original strain. In the same way, a cadmium-resistant line of Chlorella sp., with an EC50 of 3.92 $\mathrm{mg} / \mathrm{L}$, was found to produce more metallothioneins than the sensitive line with an EC50 of $0.336 \mathrm{mg} / \mathrm{L}$ [26]. Also, Rijstenbil et al. [27] observed in the diatomsDitylum brightwelli and Thalassiosira pseudonana the appearance of compounds with thiol groups after exposure to several metals (cadmium, copper, and zinc); these compounds were identified as class III metallothioneins.

Cadmium is the most studied metal regarding class III metallothioneins, because this metal is one of the best inducers of these polypeptides [28]. Ahner and Morel [25] found that the concentration of intracellular class III metallothioneins in Thalassiosira weissflogii, Tetraselmis maculata, andEmiliania huxleyi increased after the addition of cadmium. These microalgae 
were exposed to $\mathrm{Cd}, \mathrm{Pb}, \mathrm{Ni}, \mathrm{Cu}, \mathrm{Zn}, \mathrm{Co}, \mathrm{Ag}$, and $\mathrm{Hg}$. Cadmium was the most effective inducer of class III metallothioneins in these three marine microalgae.

In this study, the ability of $T$. suecica cells to synthesize class III metallothioneins as a mechanism of tolerance to cadmium was demonstrated. These microalgal cells produced net quantities of thiols when they were exposed to cadmium (Fig. 2), and these thiols were identified as class III metallothioneins (Fig. 4).

As in those of other microalgae, class III metallothionein concentration increased in $T$. suecica cells with metal exposure. In this study, metal analysis showed that approximately $87 \%$ of the cadmium that accumulated in T. suecica was bound by class III metallothioneins. Torres et al. [21] found thatPhaeodactylum tricornutum cells bound $60 \%$ of cellular cadmium as cadmium-binding complexes. These polypeptides would be acting as chelating molecules of cadmium and, therefore, cooperating in a possible mechanism of tolerance to this metal.

Capillary electrophoresis was performed to characterize the thiol-containing molecules that accumulated in response to cadmium in the microalga $T$. suecica. The traditional technique for an analysis of this kind of molecules is HPLC [11]. Recently, capillary electrophoresis has been used for the separation of class I and class III metallothioneins, showing that this technique is a very efficient tool with a high separation efficiency $[\mathbf{2 9 , 3 0 ]}$. This technique also allows the length of the metallothioneins to be determined [21]. A similar method described by Torres et al. [21] was employed in this separation, but with the modification that $2 \%(\mathrm{v} / \mathrm{v})$ acetonitrile was added to the running buffer. The addition of organic modifier resulted in sharper class III metallothionein peaks and increased resolution.

The length of the class III metallothioneins synthesized is of great interest. The $T$. suecica cells exposed to $6 \mathrm{mg} / \mathrm{L}$ of cadmium for $6 \mathrm{~d}$ are able to synthesize metallothioneins with three to six subunits of ( $\gamma$-Glu-Cys) (Fig. 4). The most abundant polypeptide detected by this technique was $(\gamma \text {-Glu-Cys })_{4}$-Gly, and the largest detected had six subunits.

One of the roles of class III metallothioneins is to protect against the toxic effects of metals, because immobilized metals are less toxic than free ions. Microalgae that are able to synthesize metallothioneins with higher chain lengths are more tolerant of metals, because long-chain metallothioneins are more efficient at binding metals. Thus, Kaplan et al. [26] found that the differences between resistant and sensitive strains of Chlorella sp. were an increase in class III metallothionein concentration and the appearance of longer metallothioneins in the tolerant cells. The EC50 was $3.92 \mathrm{mg} / \mathrm{L}$ of cadmium in the resistant line and $0.336 \mathrm{mg} / \mathrm{L}$ of cadmium in the sensitive line. 
The class III metallothioneins found in P. tricornutum cells have from four to nine subunits of ( $\gamma$-Glu-Cys). The most abundant polypeptide had five subunits, and the largest polypeptide was $\left(\gamma\right.$-Glu-Cys) ${ }_{9}$-Gly [21]. In this diatom, growth was inhibited at $10 \mathrm{mg} / \mathrm{L}$ of cadmium, and the EC50 was $22 \mathrm{mg} / \mathrm{L}$. Therefore, T. suecica would be among the microalgae most tolerant of cadmium, because it is able to synthesize longer class III metallothioneins than other microalgae. Production of these long-chain complexes could contribute to higher cadmium tolerance by more effective metal sequestration. Thus, tolerance to cadmium could be due not only to an increase in the concentration of these cadmium-binding polypeptides but, also, to the length of these polypeptides.

Isolation or selection of microalgal strains that are more tolerant to the toxic effects of metals, such as cadmium, is important, because these microalgae can be utilized in removing metals from polluted water. Knowing the mechanisms that contribute to metal tolerance may help to improve the efficiency of removing these metals.

\section{ACKNOWLEDGEMENTS}

The authors thank Servicios Generatel de Apoyo a la Investigación from Universidad de La Coruña for inductively coupled plasma analyses, especially to Alicia Cantarero, who performed them, for generously providing this information.

\section{REFERENCES}

1. Bryan GW, Langston WJ. 1992. Bioavailability, accumulation and effects of heavy metals in sediments with special reference to United Kingdom estuaries: A review.Environ Pollut 76: 89-131.

2. Rai LC, Gaur JP, Kumar HD. 1981. Phycology and heavy-metal pollution. Biol Rev 56:99151.

3. Vymazal J. 1987. Toxicity and accumulation of cadmium with respect of algae and cyanobacteria: A review. Toxicol Assess 2: 387-415.

4. Gekeler W, Grill E, Winnnacker E-L, Zenk MH. 1988. Algae sequester heavy metals via synthesis of phytochelatin complexes. Arch Microbiol 150: 197-202.

5. Robinson NJ. 1989. Algal metallothioneins: Secondary metabolites and proteins. $J$ Phycol 1: 5-18.

6. Wikfors GH, Neeman A, Jackson PJ. 1991. Cadmium-binding polypeptides in microalgal strains with laboratory-induced cadmium tolerance. Mar Ecol Prog Ser 79: 163-170. 
7. Ahner BA, Kong S, Morel FMM. 1995. Phytochelatin production in marine algae. 1. An interspecies comparison. Limnol Oceanogr 40: 649-657.

8. Kneer R, Zenk MH. 1992. Phytochelatins protect plant enzymes from heavy metals poisoning. Phytochemistry 31: 2663-2667.

9. Thumann J, Grill E, Winnacker E-L, Zenk MH. 1991. Reactivation of metal-requiring apoenzymes by phytochelatin-metal complexes. FEBS Lett 284: 66-69.

10. Robinson NJ. 1990. Metal-binding polypeptides in plants. In ShawAJ, ed, Heavy Metal Tolerance in Plants: Evolutionary Aspects. CRC, Boca Raton, FL, USA, pp 195-214.

11. Grill E, Löffler S, Winnacker E-L, Zenk MH. 1989. Phytochelatins, the heavy-metalbinding peptides of plants, are synthesized from glutathione by a specific $\gamma$ glutamylcysteine dipeptidyl transpeptidase (phytochelatin synthase). Proc Natl Acad Sci U S A 86: 6838-6842.

12. Rauser WE. 1995. Phytochelatins and related peptides. Structure, biosynthesis and function. Plant Physiol 109: 1141-1149.

13. Zenk MH. 1996. Heavy metal detoxification in higher plants-A review. Gene 179:21-30.

14. Ortiz DF, Kreppel L, Speiser DM, Scheel G, McDonald G, Ow DW. 1992. Heavy metal tolerance in the fission yeast requires an ATP-binding cassette-type vacuolar membrane transporter. EMBO J 11: 3491-3499.

15. Vögeli-Lange R, Wagner GJ. 1990. Subcellular localization of cadmium-binding peptides in tobacco leaves. Plant Physiol 92: 1086-1093.

16. Finney DJ. 1964. Probit Analysis. Cambridge University Press, London, UK.

17. Fábregas J, Herrero C, Cabezas B, Abalde J. 1986. Biomass production and biochemical composition in mass cultures of the marine microalga Isochrysis galbana Parke at varying nutrient concentrations. Aquaculture 53: 101-113.

18. Ellman GL. 1959. Tissue sulfhydryl groups. Arch Biochem Biophys 82: 70-77.

19. Barkholt V, Jensen AL. 1989. Amino acid analysis: Determination of cysteine plus halfcystine in proteins after hydrochloric acid hydrolysis with a disulfide compound as additive. Anal Biochem 177: 318-322.

20. Godel H, Seitz P, Verhoef M. 1991. Automated amino acid analysis using combined OPA and FMOC-CI precolumn derivatization. LC-GC Int 5: 44-49.

21. Torres E, Cid A, Fidalgo P, Herrero C, Abalde J. 1997. Long-chain class III metallothioneins as a mechanism of cadmium tolerance in the marine diatom Phaeodactylum tricornutum Bohlin. Aquat Toxicol 39: 231-246.

22. Wong PTS, Couture P. 1986. Toxicity screening using phytoplankton. In DutkaBJ,BittonG, eds, Toxicity Testing Using Microorganisms, Vol 2. CRC, Boca Raton, FL, USA, pp 79100. 
23. Guanzon NG, Nakahara H, Yoshida Y. 1994. Inhibitory effects of heavy metals on growth and photosynthesis of three freshwater microalgae. Fish Sci 60: 379-384.

24. Okamoto OK, Asana CS, Aidar E, Colepicolo P. 1996. Effects of cadmium on growth and superoxide dismutase activity of the marine microalga Tetrsaselmis gracilis (Prasinophyceae). J Phycol 32: 74-79.

25. Ahner BA, Morel FMM. 1995. Phytochelatin production in marine algae. 2. Induction by various metals. Limnol Oceanogr 40: 658-665.

26. Kaplan D, Heimer YM, Abeliovich A, Goldsbrough PB. 1995. Cadmium toxicity and resistance in Chlorella sp. Plant Sci 109: 129-137.

27. Rijstenbil JW, Sandee A, Van Drie J, Wijnholds JA. 1994. Interaction of toxic trace metals and mechanisms of detoxification in the planktonic diatoms Ditylum brightwellii and Thalassiosira pseudonana. FEMS Microbiol Rev 14: 387-396.

28. Steffens JC. 1990. The heavy metal-binding peptides of plants. Annu Rev Plant Physiol Plant Mol Biol 41: 553-575.

29. Virtanen V, Bordin G, Rodriguez A-R. 1996. Separation of metallothionein isoforms with capillary zone electrophoresis using an uncoated capillary column. Effects of $\mathrm{pH}$, temperature, voltage, buffer concentration and buffer composition. J Chromatogr A 734: $391-400$.

30. Torres E, Cid A, Fidalgo P, Abalde J. 1997. Rapid assay for the analysis of class III metallothioneins by capillary zone electrophoresis in crude extracts of microalgal cells exposed to cadmium. J Chromatogr A 775: 339-347. 